"The effect of sustainability accounting disclosures on financial performance: an empirical study on the Jordanian banking sector"

\begin{tabular}{|c|c|}
\hline AUTHORS & $\begin{array}{l}\text { Othman Hel Al-Dhaimesh id https://orcid.org/0000-0003-2861-1869 } \\
\text { Mo’taz Kamel Al Zobi (D https://orcid.org/0000-0003-4930-3777 }\end{array}$ \\
\hline ARTICLE INFO & $\begin{array}{l}\text { Othman Hel Al-Dhaimesh and Mo'taz Kamel Al Zobi (2019). The effect of } \\
\text { sustainability accounting disclosures on financial performance: an empirical } \\
\text { study on the Jordanian banking sector. Banks and Bank Systems, 14(2), 1-8. } \\
\text { doi:10.21511/bbs.14(2).2019.01 }\end{array}$ \\
\hline DOI & http://dx.doi.org/10.21511/bbs.14(2).2019.01 \\
\hline RELEASED ON & Thursday, 11 April 2019 \\
\hline RECEIVED ON & Saturday, 08 December 2018 \\
\hline \multirow[t]{2}{*}{ ACCEPTED ON } & Monday, 25 March 2019 \\
\hline & $(\mathrm{cc}) \mathrm{EY}_{\mathrm{EY}}$ \\
\hline LICENSE & $\begin{array}{l}\text { This work is licensed under a Creative Commons Attribution } 4.0 \text { International } \\
\text { License }\end{array}$ \\
\hline JOURNAL & "Banks and Bank Systems" \\
\hline ISSN PRINT & $1816-7403$ \\
\hline ISSN ONLINE & $1991-7074$ \\
\hline PUBLISHER & LLC "Consulting Publishing Company "Business Perspectives" \\
\hline FOUNDER & LLC "Consulting Publishing Company "Business Perspectives" \\
\hline
\end{tabular}

NUMBER OF REFERENCES

26

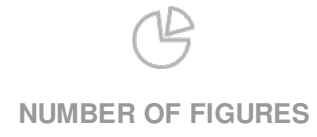

0
NUMBER OF TABLES

6

(C) The author(s) 2022. This publication is an open access article. 


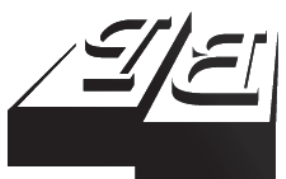

BUSINESS PERSPECTIVES

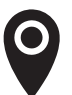

LLC "CPC "Business Perspectives" Hryhorii Skovoroda lane, 10, Sumy, 40022, Ukraine

www.businessperspectives.org

Received on: $8^{\text {th }}$ of December, 2018 Accepted on: 25 th of March, 2019

(C) Othman Hel Al-Dhaimesh, Mo'taz Kamel Al Zobi, 2019

Othman Hel Al-Dhaimesh, Doctor, Accounting Department, Ahmed Bin Mohammed Military College, Qatar.

Mo’taz Kamel Al Zobi, Doctor, Business Faculty, Amman Arab University, Jordan.

\title{
THE EFFECT OF SUSTAINABILITY ACCOUNTING DISCLOSURES ON FINANCIAL PERFORMANCE: AN EMPIRICAL STUDY ON THE JORDANIAN BANKING SECTOR
}

\begin{abstract}
This study aims to examine the effect of sustainability accounting disclosure on the financial performance of banks operating in Jordan during the period of 2013-2017. The study focused on the effect of economic, environmental and social disclosures on financial performance.

To achieve the study objective, the content analysis method was used. The dimensions of sustainability accounting disclosure were measured through indicators that have been developed for this purpose, which are in accordance with Global Reporting Initiative (GRI) (G4-2013).

The study results revealed that there is a statistically significant effect of sustainability accounting disclosure on the financial performance. In addition, the study results revealed that the disclosure of the economic and social dimensions had a positive effect on return on equity (ROE). While the environmental dimension did not affect the return on equity (ROE). In addition, the results of the study revealed that the disclosure of sustainability dimensions (economic, social and environment) had a combined effect on the return on assets (ROA). This means that the banks operating in Jordan give more priority to the economic dimension disclosure, than to the social and environmental dimensions.

In reviewing previous studies in the accounting literature, it has been found that there is a paucity of studies that examine the concept of sustainability accounting, especially in the Jordanian banking sector. Therefore, this study constitutes value to this field.
\end{abstract}

\section{Keywords}

JEL Classification

sustainability accounting, economic, social, environment, financial performance

G21, M41

\section{INTRODUCTION}

The concept of sustainable development was established between 1972 and 1992 through a series of summits and other conferences. Sustainability concept was first presented at the United Nations Conference on the Human Environment, held in Stockholm in 1972. It was the first international consultation meeting on the concept of sustainability on a global scale. The conference resulted in a series of recommendations that led to the establishment of the United Nations Environment Program (UNEP), as well as the emergence of several national environmental protection agencies. In 1983, the United Nations met with the World Commission on Environment and Development under the chairmanship of former Norwegian Prime Minister Gro Harlem. A committee has been set up to address growing concerns about the collapse of the human environment and natural resources and the effects of this collapse on economic and social development. Four years later, the Group published a report to address these issues entitled "Our Common Future", also known as the Brundtland Report - 1987. The report provided an accurate analysis of 
the state of the environment as well as the dissemination of the most commonly used definition of sustainable development as: "Sustainable development meets the needs of the present without compromising the ability of future generations to meet their own needs" (WCED, 1987).

In this context, in 1997 The Global Reporting Initiative (GRI) was founded as an international independent organization that helps businesses, governments and other organizations communicate their impact on critical sustainability issues such as climate change, human rights, and corruption. The aim was to create an accountability mechanism to ensure companies were following the principles for responsible environmental conduct. The GRI developed the concept of sustainability by linking economy, environment and society dimensions together, and these three converge over long-term time horizons, so that none of these three components can be viewed separately (GRI, 2015, 2016).

The process of sustainability disclosure aims to assess the economic, social and environmental aspects of a company and banks (D'Andrea, 2017) and to present a comprehensive summary of the knowledge provided by these companies and banks for social achievement towards them. It is also a vital intellectual step to achieve intelligent, sustainable and comprehensive growth that combines long-term profitability, social equity and environmental care for those who are reporting on these reports (European Commission, 2015).

Recently, financial reports that are focused on economic disclosure have limited value for interested parties such as stockholders and investors, which fails to provide useful information that enables interested users to assess market value of the company. The Institute of Chartered Accountants in England and Wales noted that the insufficiency of financial reporting and its inability to provide the basic needs of investors were one of the reasons for Financial Crises in 2008. As a result, there is a considerable pressure on the accounting profession to change its traditional role, and claims that are calling for the need to include financial reports disclosures along with the results of the economic performance as well as the results of social and environmental performance of business organization, which is known as sustainability accounting (GRI, 2016).

The disclosure of sustainability in the Middle East and especially in banks operating in Jordan is voluntary. There is no law or regulations requiring companies or banks to disclosure the sustainability dimensions. Therefore, some companies and banks are fully or partially disclosing the dimensions of sustainability. Accordingly, the study aims to test the impact of sustainability accounting disclosure on the financial performance of Jordanian banking sector according to G4 reports published by Global Reporting Initiative (GRI).

\section{LITERATURE REVIEW AND PREVIOUS STUDIES}

Banks are operating in a global competitive environment. They too face the environmental pressures. Sustainability is the most important concept that is widespread today. GRI (2013) report reveals that for companies that prepare sustainability reports separately, it is easier to disseminate information with stakeholders.

\subsection{Sustainability concept}

The Global Reporting Initiative (GRI) defined the process of sustainability as the practices of measurement, disclosure and accountability to internal and external stakeholders for the organization's performance towards sustainable development, making theoretical issues concrete and specific, helping to understand and managing the impact of sustainability developments on the organization activities and strategy (GRI, 2013). KPMG (2013) defines sustainability as the assessment and dissemination of quantitative and qualitative information on the economic, social and environmental performance of the company in a balanced manner in relation to the environment and the community of which it is a part.

Macintoch and Wilkinson (2012) argue that sustainability disclosure is intended to provide an analysis of the companies performance at a given time to influence corporate perceptions and 
to legitimize their activities. Caesaria and Basuki (2017) point out that the process of disclosuring sustainability is important for investors due to two aspects. The first is that environmental and social performance is essential for social and environmental analysis. Financial disclosure cannot directly disclose risks. Secondly, increasing investor interest in environmental and social risks as important indicators of corporate efforts to improve corporate governance and increase transparency.

The Global Reporting Initiative (GRI) noted that sustainability is a vital step towards a sustainable global economy by strengthening corporate accountability for the impact of its activities, as well as enhancing confidence and sharing the values on which society is built to make it more cohesive. In addition, it allows governments to assess the contribution of companies to economic development and a more comprehensive understanding of the issues addressed by the actors (GRI, 2013).

\subsection{Sustainability dimensions}

According to the Sustainability Report published by the Global Reporting Initiative (GRI) (2013), the disclosure of sustainability accounting is comprised of three dimensions:

1) economic dimension;

2) social dimension; and

3) environmental dimension.

\subsubsection{Economic dimension and financial performance}

The economic dimension of sustainability measures the extent to which stakeholders, economic systems at local, national and global levels are affected by the organization's activities. The economic dimension consists of four major aspects: economic performance, market presence, indirect economic impact and procurement practices (GRI, 2013).

Most of studies (Caesaria \& Basuki, 2017; Nnamani et al., 2017; Aggarwal, 2013; Burhan \& Rahmanti, 2012) concluded that the disclosure of the economic dimension led to an improvement in the organization financial performance by improving the confidence of potential investors and creditors, thereby enhancing the image of the organization.

\subsubsection{Social dimension and financial performance}

The social dimension relates to the impact of the organization's operations and activities on society as a whole. The social dimension consists of four major aspects: labor practices and decent work, human rights, society and product responsibility (GRI, 2013).

Most of studies (Caesaria \& Basuki, 2017; Platonova et al., 2017; Nevado-Peña et al., 2015) concluded that the disclosure of the social dimension led to an improvement in the organization financial performance.

\subsubsection{Environmental dimension and financial performance}

This dimension concerns with preservation and development of the biological and ecological material resource base, by taking into account environmental considerations that ensure that waste does not exceed the current and future capacity of the environment. The environment dimension consists of four major aspects: energy, water, emissions and materials (GRI, 2013).

Most of studies (Ezejiofor et al., 2017; Ong et al., 2016; Gatimbu \& Wabwire, 2016; Nevado-Peña et al., 2015; Rokhmawatia et al., 2015; Ong et al., 2014; Ratri \& Dewi, 2017; Iqbal et al., 2013; Dragomir, 2010; Olayinka \& Oluwamayowa, 2014) concluded that the disclosure of the environment dimension resulted in an improvement in the organization financial performance.

\subsection{Banking system in Jordan}

There are 25 banks operating in Jordan, including 16 local Jordanian banks, which are divided into 13 commercial banks, Islamic banks, nine foreign banks, eight commercial three banks and one Islamic bank. According to the Association of Banks in Jordan, the number of branches of these banks by the end of 2017 was 786 . The bank density index by the end of 2017 accounted for about 12,127 people per branch. In comparison to the size of the Jordanian economy, Jordan's banking sector assets accounted for $173 \%$ of nominal GDP by the end of 2017. Deposits accounted for $116 \%$ of 
GDP and loans for $113 \%$, reflecting the contribution of the banking sector to economic and social development in Jordan (Association of Banks in Jordan, 2017).

\section{RESEARCH METHODOLOGY}

\subsection{Study sample and data}

The study data were obtained using content analysis of sustainability reports and annual reports published by Jordanian banks during the period of 2013-2017. The study sample consists of 11 banks selected based on sustainability data availability. Table 1 shows how the study sample was selected.

Table 1. Study sample selection

\begin{tabular}{l|c}
\hline Total number of banks operating in Jordan & 25 \\
\hline $\begin{array}{l}\text { Minus: banks do not disclose sustainability } \\
\text { indicators }\end{array}$ & 14 \\
\hline Equals: total banks eligible for sample & 11 \\
\hline
\end{tabular}

\subsection{Research hypothesis}

Based on the literature review and study objective, the main research hypothesis has been formulated as follows:

$H_{0}: \quad$ There is no statistically significant effect of sustainability accounting disclosure on the financial performance of banks operating in Jordan.

Sub-hypotheses are subdivided as follows:

$H_{01}$ : There is no statistically significant effect of sustainability accounting disclosure on the return on equity (ROE) of banks operating in Jordan.

$H_{02}$ : There is no statistically significant effect of sustainability accounting disclosure on the return on assets (ROA) of banks operating in Jordan.

\subsection{Measurement of variables and study models}

\subsubsection{Independent variables}

The independent variables measures were built based on measurements published by the Global Reporting Initiative (GRI) (2013), as shown in Table 2.
Table 2. Sustainability accounting disclosures

\begin{tabular}{|c|c|c|}
\hline Variable & Aspect & Measures \\
\hline \multirow{7}{*}{$\begin{array}{l}\text { Environmental } \\
\text { dimension } \\
\text { (independent } \\
\text { variable) }\end{array}$} & \multirow{2}{*}{ Materials } & $\begin{array}{l}\text { Disclosure of plastic } \\
\text { bottles consumption }\end{array}$ \\
\hline & & $\begin{array}{l}\text { Disclosure of paper } \\
\text { consumption }\end{array}$ \\
\hline & \multirow{3}{*}{ Energy } & $\begin{array}{l}\text { Disclosure of vehicle } \\
\text { fuel consumption }\end{array}$ \\
\hline & & $\begin{array}{l}\text { Disclosure of heating } \\
\text { fuel consumption }\end{array}$ \\
\hline & & $\begin{array}{l}\text { Disclosure of electricity } \\
\text { consumption }\end{array}$ \\
\hline & Water & $\begin{array}{l}\text { Disclosure of water } \\
\text { consumption }\end{array}$ \\
\hline & Emissions & $\begin{array}{l}\text { Disclosure of } \\
\text { greenhouse gas } \\
\text { emissions }\end{array}$ \\
\hline \multirow{14}{*}{$\begin{array}{l}\text { Social } \\
\text { dimension } \\
\text { (independent } \\
\text { variable) }\end{array}$} & \multirow{4}{*}{ Employees } & $\begin{array}{l}\text { Disclosure of } \\
\text { employment policies }\end{array}$ \\
\hline & & $\begin{array}{l}\text { Disclosure of training } \\
\text { and education projects }\end{array}$ \\
\hline & & $\begin{array}{l}\text { Disclosure of diversity } \\
\text { and equal opportunity } \\
\text { between employees }\end{array}$ \\
\hline & & $\begin{array}{l}\text { Disclosure of equal } \\
\text { remuneration for } \\
\text { women and men }\end{array}$ \\
\hline & \multirow[b]{2}{*}{ Human rights } & $\begin{array}{l}\text { Disclosure of charitable } \\
\text { projects }\end{array}$ \\
\hline & & $\begin{array}{l}\text { Disclosure of } \\
\text { beneficiaries of } \\
\text { charitable projects }\end{array}$ \\
\hline & \multirow{4}{*}{$\begin{array}{l}\text { Product } \\
\text { responsibility }\end{array}$} & $\begin{array}{l}\text { Disclosure of research } \\
\text { and development costs }\end{array}$ \\
\hline & & $\begin{array}{l}\text { Disclosure of marketing } \\
\text { and distribution } \\
\text { expenses }\end{array}$ \\
\hline & & $\begin{array}{l}\text { Disclosure of new } \\
\text { products }\end{array}$ \\
\hline & & $\begin{array}{l}\text { Disclosure of number } \\
\text { of branches }\end{array}$ \\
\hline & \multirow{4}{*}{ Social } & $\begin{array}{l}\text { Disclosure of social } \\
\text { projects }\end{array}$ \\
\hline & & $\begin{array}{l}\text { Disclosure of } \\
\text { investment in the local } \\
\text { community }\end{array}$ \\
\hline & & $\begin{array}{l}\text { Disclosure of number } \\
\text { of volunteering } \\
\text { employees in local } \\
\text { community services }\end{array}$ \\
\hline & & $\begin{array}{l}\text { Disclosure of annual } \\
\text { donations }\end{array}$ \\
\hline \multirow{4}{*}{\multicolumn{2}{|c|}{$\begin{array}{l}\text { Economic dimension } \\
\text { (independent variable) }\end{array}$}} & $\begin{array}{l}\text { Disclosure of economic } \\
\text { performance }\end{array}$ \\
\hline & & $\begin{array}{l}\text { Disclosure of market } \\
\text { presence }\end{array}$ \\
\hline & & $\begin{array}{l}\text { Disclosure of indirect } \\
\text { economic impact }\end{array}$ \\
\hline & & $\begin{array}{l}\text { Disclosure of } \\
\text { procurement practices }\end{array}$ \\
\hline
\end{tabular}




\subsubsection{Dependent variables}

Table 3. Financial performance measures

\begin{tabular}{l|c:c}
\hline \multicolumn{1}{c|}{ Variable } & Aspect & Measures \\
\hline $\begin{array}{l}\text { Financial } \\
\text { performance } \\
\text { (dependent } \\
\text { variable) }\end{array}$ & $\begin{array}{c}\text { Return on assets } \\
\text { (ROA) }\end{array}$ & $\begin{array}{c}\text { Net income/ } \\
\text { Total assets }\end{array}$ \\
\hline & $\begin{array}{c}\text { Return on equity } \\
\text { (ROE) }\end{array}$ & $\begin{array}{c}\text { Net income/ } \\
\text { Shareholder's equity }\end{array}$ \\
\hline
\end{tabular}

\subsubsection{Study models}

To examine the impact of sustainability accounting disclosures on financial performance, the linear regression equation was designed.

$$
\begin{aligned}
& R O E_{i t}=\alpha_{0}+\beta_{1} E N V_{i t}+ \\
& +\beta_{2} S O C_{i t}+\beta_{3} E C O_{i t}+\varepsilon_{i t}, \\
& R O A_{i t}=\alpha_{0}+\beta_{1} E N V_{i t}+ \\
& +\beta_{2} S O C_{i t}+\beta_{3} E C O_{i t}+\varepsilon_{i t},
\end{aligned}
$$

where $\beta_{1}, \beta_{2}, \beta_{3}$ - coefficients of independent variables, $E N V$ - environmental dimension, SOC social dimension, ECO - economic dimension, $\varepsilon$ random error.

\section{DATA ANALYSIS AND HYPOTHESES TESTING}

\subsection{Testing the main hypothesis ( $\mathrm{Ho})$}

There is no statistically significant effect of sustainability accounting disclosure on the financial performance of banks operating in Jordan. Table 4 shows the results of this hypothesis testing.
In terms of independent variables, Table 4 shows that the relationship value $r$ of the sustainability accounting dimensions with the dependent variable (financial performance) reached 0.811 . This relation is statistically significant, the value of F-test is 43.54 and the value of the significance level is less than 0.05 . This means accepting this relationship statistically.

As shown in Table 4, all the variables of the independent study were accepted statistically. The values of the t-test significance level were less than 0.05 , which means that there is a linear effect of each dimension of sustainability on the financial performance of the Jordanian banks. The value of $\mathrm{R}^{2}$ indicates that the independent variables (sustainability accounting dimensions) accounted for $68.3 \%$ of the change in the dependent variable (financial performance).

Accordingly, the null hypothesis is rejected. The alternative hypothesis is accepted as follows: There is a statistically significant effect of sustainability accounting disclosure on the financial performance of banks operating in Jordan.

\subsubsection{Testing the first sub-hypothesis (Ho1)}

There is no statistically significant effect of sustainability accounting disclosure on the return on equity (ROE) of banks operating in Jordan. Table 5 shows the results of the first sub-hypothesis testing.

Table 5 shows that the relationship value $r$ of the sustainability accounting dimensions with the dependent variable ROE reached 0.812 . This rela-

\begin{tabular}{|c|c|c|c|c|c|c|c|c|}
\hline & endent variables & $\boldsymbol{R}$ & $\boldsymbol{R}^{2}$ & $\boldsymbol{F}$ & Sig. $f$ & $\beta$ & $t$ & Sig. $t$ \\
\hline \multirow{3}{*}{ Dimension } & Environmental dimension & \multirow{3}{*}{0.811} & \multirow{3}{*}{0.683} & \multirow{3}{*}{43.54} & \multirow{3}{*}{0.000} & 0.141 & 4.623 & 000.0 \\
\hline & Social dimension & & & & & 0.156 & 4.699 & 0.000 \\
\hline & Economic dimension & & & & & 0.191 & 3.448 & 0.001 \\
\hline
\end{tabular}
tion is statistically significant, the value of F-test is 91.11 and the value of the significance level is less

\begin{tabular}{|c|c|c|c|c|c|c|c|c|}
\hline \multicolumn{2}{|c|}{ Independent variables } & $\boldsymbol{R}$ & $R^{2}$ & $\boldsymbol{F}$ & Sig. $f$ & $\begin{array}{c}\beta \\
\text { non-normative } \\
\end{array}$ & $t$ & Sig. $t$ \\
\hline \multirow{3}{*}{ Dimension } & Environmental dimension & \multirow{3}{*}{0.812} & \multirow{3}{*}{0.787} & \multirow{3}{*}{91.11} & \multirow{3}{*}{0.000} & 0.042 & 0.998 & 0.320 \\
\hline & Social dimension & & & & & 0.235 & 7.473 & 0.000 \\
\hline & Economic dimension & & & & & 0.244 & 4.281 & 0.000 \\
\hline
\end{tabular}

Table 4. Results of the main hypothesis testing

Table 5. Results of the first sub-hypothesis testing 
Table 6. Results of the second sub-hypothesis testing

\begin{tabular}{|c|c|c|c|c|c|c|c|c|}
\hline \multicolumn{2}{|c|}{ Independent variables } & $\boldsymbol{R}$ & $R^{2}$ & $\boldsymbol{F}$ & Sig. $f$ & $\beta$ non-normative & $t$ & Sig. $t$ \\
\hline \multirow{3}{*}{ Dimension } & Environmental dimension & \multirow{3}{*}{0.611} & \multirow{3}{*}{0.312} & \multirow{3}{*}{22.14} & \multirow{3}{*}{0.000} & 0.133 & 2.83 & 0151.0 \\
\hline & Social dimension & & & & & 0.292 & 5.95 & 0000.0 \\
\hline & Economic dimension & & & & & 0.185 & 2.25 & 0.0261 \\
\hline
\end{tabular}

than 0.05 . This means accepting this relationship statistically.

As shown in Table 5, all the variables of the independent study were accepted statistically. The values of the t-test significance level were less than 0.05 , which means that there is a linear effect of each sustainability dimension on the ROE of the Jordanian banks. The value of $R^{2}$ indicates that the independent variables (sustainability accounting dimensions) accounted for $78.7 \%$ of the change in the dependent variable of ROE.

The value of the coefficient $\beta$ shows the extent of the effect of the independent variable on the dependent variable. The value of the effect is 0.244 for the economic dimension variable, 0.235 for the social dimension variable. It is noted that the economic dimension had the greatest impact on ROE. While the environmental dimension did not affect the return on equity, the beta coefficient was 0.042 and was not statistically significant.

Accordingly, the null hypothesis is rejected. The alternative hypothesis is accepted as follows: There is a statistically significant effect of sustainability accounting disclosure on the return on equity (ROE) of banks operating in Jordan.

\subsubsection{Testing the second sub-hypothesis (H02)}

The second sub-hypothesis states: There is no statistically significant effect of sustainability accounting disclosure on the return on assets (ROA) of banks operating in Jordan. Table 6 shows the results of the hypothesis testing.

Table 6 shows that the relationship value $r$ of the sustainability accounting dimensions with the dependent variable ROA reached 0.611 . This relation is statistically significant. The value of F-test is 22.14 and the value of the significance level is less than 0.05 . This means accepting this relationship statistically.

As shown in Table 6, all the variables of the independent study were accepted statistically. The values of the t-test significance level were less than 0.05 , which means that there is a linear effect of each dimension of sustainability on the ROA of the Jordanian banks. The value of $R^{2}$ indicates that the independent variables (sustainability accounting dimensions) accounted for $31.2 \%$ of the change in the dependent variable of ROA.

The value of the coefficient $\beta$ shows the extent of the effect of the independent variable on the dependent variable. The value of the effect is 0.292 for the social dimension variable, 0.185 for the economic dimension variable, and 0.133 for the environmental dimension variable. It is noted that the social dimension had the greatest impact on return on equity.

Accordingly, the null hypothesis is rejected. The alternative hypothesis is accepted as follows: There is a statistically significant effect of sustainability accounting disclosure on the return on assets (ROA) of banks operating in Jordan.

\section{CONCLUSION}

The study results revealed that there is a statistically significant effect of sustainability accounting disclosure on financial performance of banks operating in Jordan. This is a clear indication that banks are considered annual reports readers at a high-level knowledge. This makes it possible to connect the level of disclosure of the sustainability dimensions and the behavior of society towards dealing with the bank. 
In addition, the study results revealed that the disclosure of the economic and social disclosure had a statistically significant effect on the return on equity ROE. While the environment disclosure does not have an effect on return on equity (ROE). In addition, the results of the study revealed that the disclosure of the sustainability dimensions (economic, social and environment) had a combined significant effect on the return on assets (ROA). This means that the banks operating in Jordan are very interested in disclosure of the economic dimension. In addition, less interested about the environmental dimension disclosure. Based on the findings, the study recommends the following:

- Motivate banks to focus on the environmental and social dimensions, and not to care only about the economic dimension, since banks are part of the society.

- Activate the role of sustainability accounting by creating specialized sustainability departments within banks that work according to the latest Global Reporting Initiative (GRI) standards, towards achieving sustainability goals.

- Conduct future studies related to the disclosure of sustainability accounting in other sectors and the adoption of other financial indicators.

\section{REFERENCES}

1. Aggarwal, P. (2013). Impact of Sustainability Performance of Company on its Financial Performance: A Study of Listed Indian Companies. Global Journal of Management and Business Research Finance, 13(11), 61-70. Retrieved from https://globaljournals.org/ GJMBR_Volume13/6-Impact-ofSustainability-Performan.pdf

2. Aggarwal, P. (2013). Sustainability Reports and their Impact on Corporate Financial Performance: A Literary Review. Indian Journal of Commerce and Management Studies, IV(3), 51-59. Retrieved from http://www.scholarshub.net/ ijcms/vol4/issue3/Paper_10.pdf

3. Association of Banks in Jordan. (2017). Annual Report 2017 (No. 39). Retrieved from https://static. cf.bankaletihad.com/apicms/wpcontent/uploads/2017-AnnualReport.pdf

4. Burhan, A. H. N., \& Rahmanti, W. (2012). The impact of sustainability in reporting the performance of the company. Journal of Economics, Business, and Accountancy Ventura, 15(2), 257-272. Retrieved from https:// pdfs.semanticscholar.org/711a/6e 1788e94667dbf489a219eb80172a8 3140f.pdf
5. Caesaria, A. F., \& Basuki, B. (2017). The study of sustainability report disclosure aspects and their impact on the companies' performance. SHS Web of Conferences, 34, 08001. https://doi. org/10.1051/shsconf/20173408001

6. D'Andrea, A. (2017). Applying GRI Sustainability Reporting in the Water Sector: Evidences from an Italian Company. International Journal of Business Administration, 8(3), 10-23. https://doi. org/10.5430/ijba.v8n3p10

7. European Commission. (2015). Financing Sustainable Energy Systems for Developing Countries (Background Papers). Frankfurt School - UNEP Centre, Frankfurt am Main. Retrieved from https:// ec.europa.eu/europeaid/sites/ devco/files/erd5-background-paper-financing-sustainable-energysystems-2015_en.pdf

8. Ezejiofor, R. A., Racheal, J.-A., \& Chigbo Ben Eucharia, E. C. (2016). Effect of Sustainability Environmental Cost Accounting on Financial Performance of Nigerian Corporate Organizations. International Journal of Scientific Research and Management, 4(8), 4536-4549. Retrieved from https:// ijsrm.in/index.php/ijsrm/article/ view/461/408
9. Gatimbu, K. K., \& Wabwire, J. M. (2016). Effect of Corporate Environmental Disclosure on Financial Performance of Firms Listed at Nairobi Securities Exchange, Kenya, International Journal of Sustainability Management and Information Technologies, 2(1), 1-6.

10. Global Reporting Initiative (GRI). (2013). G4, Sustainability Reporting Guidelines. Retrieved from https://www.globalreporting. org/resourcelibrary/grig4-part1 reporting-principles-and-standard-disclosures.pdf

11. Global Reporting Initiative (GRI). (2015). G4, Sustainability Reporting Guidelines (updated).

12. Global Reporting Initiative (GRI). (2016). G4, Sustainability Reporting Guidelines (updated).

13. Iqbal, M., Sutrisno, T., Assih, P., \& Rosidi. (2013). Effect of Environmental Accounting Implementation and Environmental Performance and Environmental Information Disclosure as Mediation on Company Value. International Journal of Business and Management Invention, 2(10), 5567. Retrieved from https://www. ijbmi.org/papers/Vol(2)10/Version-1/G02101055067.pdf 
14. KPMG. (2013). Advisory under the spotlight: Corporate Governance and Sustainability.

15. Macintosh, A., \& Wilkinson, D. (2012). Are we progressing? Comprehensive Monitoring and Reporting in Australia. The Australian Collaboration.

16. Nevado-Peña, D., López-Ruiz, V.R., \& Alfaro-Navarro, J.-L. (2015). The Effects of Environmental and Social Dimensions of Sustainability in Response to the Economic Crisis of European Cities. Sustainability, 7(7), 82558269. https://doi.org/10.3390/ su7078255

17. Nnamani, N. J., Onyekwelu, L. U., \& Kevin, U. O. (2017). Effect of Sustainability Accounting and Reporting on Financial Performance of Firms in Nigeria Brewery Sector. European Journal of Business and Innovation Research, 5(1), 1-15.

18. Norhasimah Md Nor, Norhabibi Aishah Shaiful Bahari, Nor Amiera Adnan, Sheh Muhammad Qamarul Ariffin Sheh Kamal, \& Ali, I. M. (2016). The Effects of Environmental Disclosure on Financial Performance in Malaysia. Procedia Economics and Finance, 35, 117-126. https://doi.org/10.1016/ S2212-5671(16)00016-2

19. Olayinka, A., \& Oluwamayowa, I. (2014). Corporate environmental disclosures and market value of quoted companies in Nigeria. The Business and Management Review, 5(3), 171-184. Retrieved from http://www.abrmr.com/myfile/ conference_proceedings/Con Pro_78450/v5n3itrac14-31.pdf

20. Ong, T. S., Teh, B. H., \& Ang, Y. W. (2014). The Impact of Environmental Improvements on the Financial Performance of Leading Companies Listed in Bursa Malaysia. International Journal of Trade, Economics and Finance, 5(5), 386-391. https://doi. org/10.7763/IJTEF.2014.V5.403

21. Ong, T. S., Tho, H. S., Goh, H. H., Thai, S. B., \& Teh, B. H. (2016). The Relationship Between Environmental Disclosures and Financial Performance of Public Listed Companies in Malaysia. International Business Management, 10(4), 461-467. Retrieved from http://medwelljournals.com/ abstract/?doi=ibm.2016.461.467

22. Platonova, E., Asutay, M., Dixon, R., \& Mohammad, S. (2016). The Impact of Corporate Social Responsibility Disclosure on Financial Performance: Evidence from the GCC Islamic Banking Sector. Journal of Business Ethics, 151(2), 451-471. https://doi. org/10.1007/s10551-016-3229-0
23. Ratri, R. F., \& Dewi, M.

(2017). The Effect of Financial Performance and Environmental Performance on Firm Value with Islamic Social Reporting (ISR) Disclosure as Intervening Variable in Companies Listed at Jakarta Islamic Index (JII). SHS Web of Conferences, 34, 12003. https://doi. org/10.1051/shsconf/20173412003

24. Rokhmawati, A., Sathye, M., \& Sathye, S. (2015). The Effect of GHG Emission, Environmental Performance, and Social Performance on Financial Performance of Listed Manufacturing Firms in Indonesia. Procedia - Social and Behavioral Sciences, 211, 461 470. https://doi.org/10.1016/j. sbspro.2015.11.061

25. Voicu, D. Dragomir (2010). Environmentally sensitive disclosures and financial performance in a European setting. Journal of Accounting \& Organizational Change, 6(3), 359-388. https://doi. org/10.1108/18325911011075222

26. WCED. (1987). Our common future (Report of the World Commission on Environment and Development). G. H. Brundtland (Ed.). Retrieved from https:// sswm.info/sites/default/files/ reference_attachments/UN\%20 WCED\%201987\%20Brundtland\%20Report.pdf 